\title{
ANALYSIS OF STRUCTURAL CHANGES CREATED BY THE BLAST EFFECT
}

\author{
Zoltán NYIKES, ${ }^{1}$ Norbert DARUKA, ${ }^{2}$ Tünde Anna KOVÁCS ${ }^{3}$ \\ ${ }^{1}$ Óbuda University, Bánki Donát Mechanical and Safety Engineering, Doctoral School on Safety and Secu- \\ rity.Budapest, Hungary, nyikes.zoltan@phd.uni-obuda.hu \\ ${ }^{2}$ Óbuda University, Bánki Donát Mechanical and Safety Engineering, Institute of Mechanical Engineering \\ and Security Sciences, Budapest, Hungary, daruka.norbi@gmail.com \\ ${ }^{3}$ Óbuda University, Bánki Donát Mechanical and Safety Engineering, Department of Materials Technology, \\ Budapest, Hungary, kovacs.tunde@bgk.uni-obuda.hu
}

\begin{abstract}
Unfortunately, people can't live in peace in this century: many wars and terrorist attacks have been witnessed even within the last year. In the case of such attacks, both the people and the civil infrastructure is in danger [1-3]. The modern age (infrastructure) provides electrical networks and communication networks for the citizens. Without electricity and/or communications (e.g. the internet), urban life is paralysed. Explosions create heat and shock waves and their effects can potentially damage the wall and cables of a building as changes in the material structure occur. In this article, the authors introduce a blast load effect testing method in an empirical way. The metal microstructure deformation level is measurable by changes in resistance, because resistance is a physical property which depends on the crystal structure of the metal.
\end{abstract}

Keywords: resistance, electrical cable, blast.

\section{Introduction}

Defence has always had a priority role throughout history. In the modern age, new materials have appeared and building technologies have become more complex. Modern standards have evolved taking into account the effects of earthquakes. Unfortunatly bomb attacks and wars are harder to consider. In Hungary, the standards for building construction against impact load are not available [4-5].

The classification of blast loads is a very difficult task because of the wide variety of explosive materials, chemical composition, physical state and volume. Innovations of Explosive materials are continuous[6].

Innovation in construction materials is slower than innovation in explosive materials.

In the case of electrical networks, the materials used are metals (aluminium, copper), while the communication network utilizes glass fibres as well.

Metals have good heat and electrical conduction capacity and plasticity [7]. These materials are convenient to use for an electrical network. The metals are sensitive to high energy and heat effects. These loads can cause micro-structural transformation which changes its mechanical and physical properties [8].

In our experiments, we examined the changes occurring in electrical copper cables created by an explosion blast.

\section{Theoretical background}

The resistance of metals depends on the metals' microstructure. Copper has a face centered cubic crystal structure, where the lattice constant is a $=0,364 \mathrm{~nm}$. The conductivity of copper is good because the lattice constant is small and the atoms share their electrons. In the case of copper 
and copper alloys, the specific resistance depends on the number of dislocations in the crystal-line structure (Figure 1.).

Conductivity is determined by $G$ the reciprocal of the resistance (1), the specific conductivity is the conductivity of the unit cable length and diameter (2).

Conductivity, where $R(\Omega)$ is the resistance:

$G=1 / R(\mathrm{~S})$

Specific conductivity is the reciprocal of the specific resistance, $\rho(\Omega \cdot \mathrm{m})$ :

$$
\sigma=1 / \rho(\mathrm{S} / \mathrm{m})
$$

where $\rho$ is the specific resistance, $A\left(\mathrm{~m}^{2}\right)$ cable cross section area, $R(\Omega)$ resistance, $l(\mathrm{~m})$ length of the cable:

$$
\rho=R A / l(\Omega \cdot \mathrm{m})
$$

The dislocation number of the crystal structure increases in accordance with the plastic deformation. The explosion wave effect creates a high energy plastic deformation, and that changes the crystal structure similar to the plastic deformation, increasing the number of dislocations [2].

\section{Experimental materials}

We wanted to investigate the effects of an explosion on copper cables. For our experiments, we used two common bricks (concrete brick, ceramic brick) prepared with $1 \mathrm{~mm}$ diameter copper cables (Figures 2-3.).

The density of the copper is $8,93 \mathrm{~g} / \mathrm{cm}^{3}$, melting temperature $1083{ }^{\circ} \mathrm{C}$, specific elongation $30-35 \%$, ultimate tensile strength $250 \mathrm{MPa}$ [10]. The bricks were coated with different layers (Figure 4.).

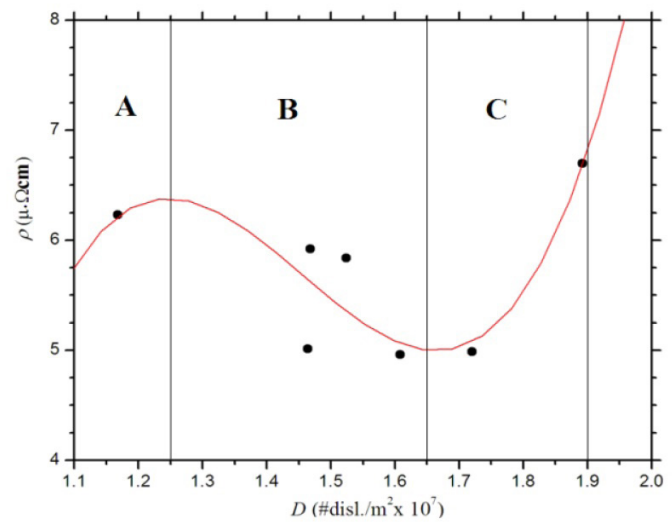

Figure 1. Specific resistance as a function of the dislocation number in unit area [9]

\section{Blasting experiment}

For the experiments, we used two different explosive materials: TNT and Semtex, in both cases, the volume used was $400 \mathrm{~g}$, the distance from the target was different. ( $2 \mathrm{~m}, 3 \mathrm{~m}$ respectively). The bricks were located on the ground on the same level as the explosive material. The experiment setup is shown in Figure 5.

The different explosive materials damaged the bricks and cables in accordance with the distance

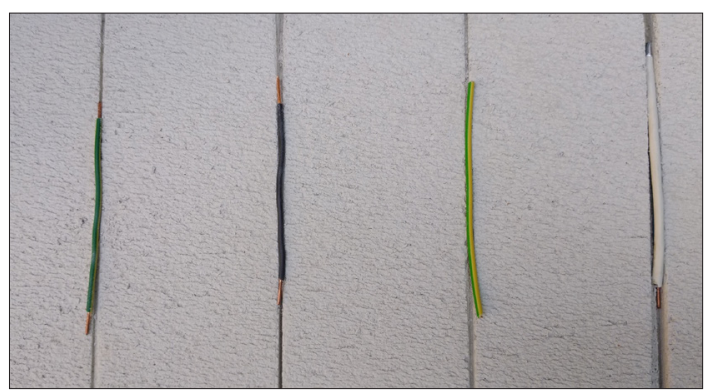

Figure 2. Concrete brick prepared with copper cables

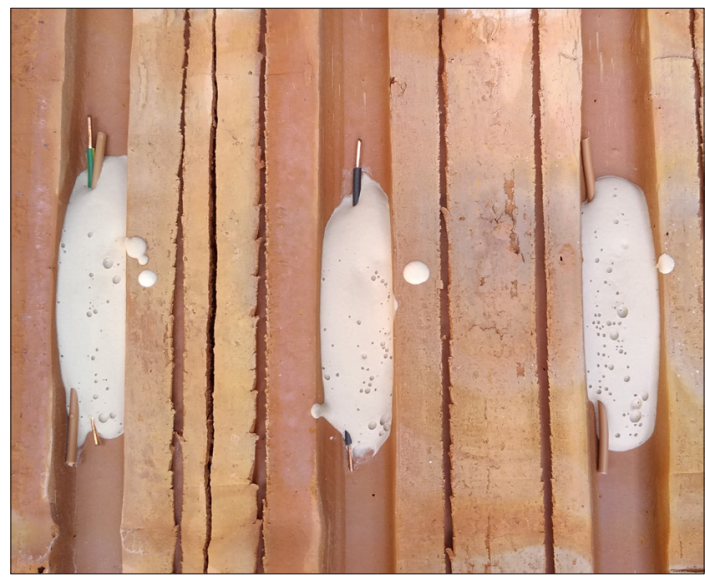

Figure 3. Ceramic brick, prepared with copper cables

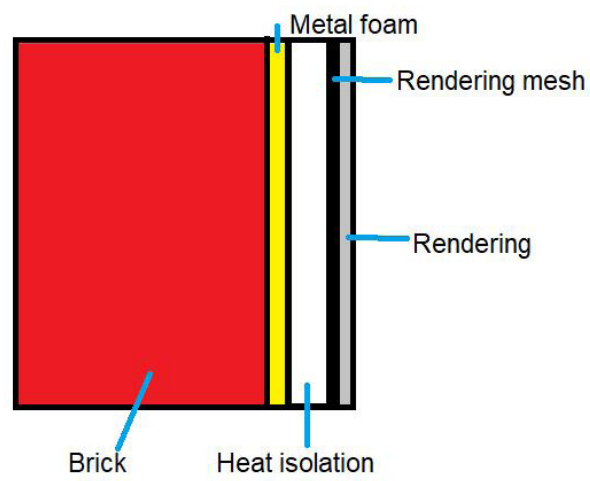

Figure 4. The tested brick with coatings 


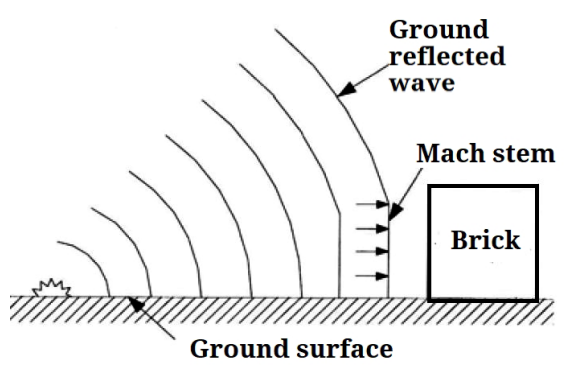

Figure 5. Setup of the surface level experiment [9]

of the explosive from the target because the blast wave load is different. The explosion's heat effect was not significant in the experimental setup

\section{Investigation of the cables}

The structural changes caused by explosion load was tested by investigation of the resistance. The high energy effects typical of explosions create changes in the metal microstructure. The metals specific conductivity depends on the grain size, lattice constant and the dislocation numbers [9]. AThe experimented cables length (100 mm) and the measured resistance, before the explosive load test (in $20^{\circ} \mathrm{C} \mathrm{R}=4 \cdot 10^{-3} \Omega$ ), was standard. After the blast load, the plastic deformation was not measured. The resistance measurement was made by Wheatstone bridge at five decimal place accuracy.

The specific resistance of the used cables was determined by (3) equation:

$$
\rho=1,256 \cdot 10^{-7}(\Omega \cdot \mathrm{m})
$$

Table 1. The test samples types

\begin{tabular}{|l|l|l|c|}
\hline $\begin{array}{c}\text { Used explo- } \\
\text { sive material }\end{array}$ & $\begin{array}{c}\text { Distance } \\
\mathbf{( m )}\end{array}$ & Brick type & $\begin{array}{c}\text { Specific } \\
\text { resistance } \\
(\cdot \mathbf{1 0}-\mathbf{\Omega} \cdot \mathbf{m})\end{array}$ \\
\hline \multirow{2}{*}{ TNT } & 2 & concrete & 1.1618 \\
\cline { 2 - 4 } & & ceramic & 1.2560 \\
\cline { 2 - 4 } & 3 & concrete & 1.1932 \\
\cline { 2 - 4 } & & ceramic & 1.1932 \\
\hline \multirow{3}{*}{ Semtex } & 2 & concrete & 1.2560 \\
\cline { 2 - 4 } & & ceramic & 1.2878 \\
\cline { 2 - 4 } & 3 & concrete & 1.3199 \\
\cline { 2 - 4 } & & ceramic & 1.2246 \\
\hline
\end{tabular}

The experimental results of specific resistance in the case of different bricks and blast distance are collected in Table 1.

\section{Results and conclusions}

We have concluded on the basis of the experimental results that the blast wave from the used explosive materials caused changes in the cables in the case of our experimental setup, the measured resistance results were not relevant, but we measured small changes in the specific resistance.

We have concluded that in the case of the electrical cables the blast caused changes in the microstructure and together with this, changes in the specific resistance. The relationship was not summarized by a mathematical equation because of the insufficient number of results.

Future plans to repeat the experiments - with higher volume explosive and smaller explosion distance - will yield relevant changes. Also, we

\section{Specific resistance as a function of the explosive}

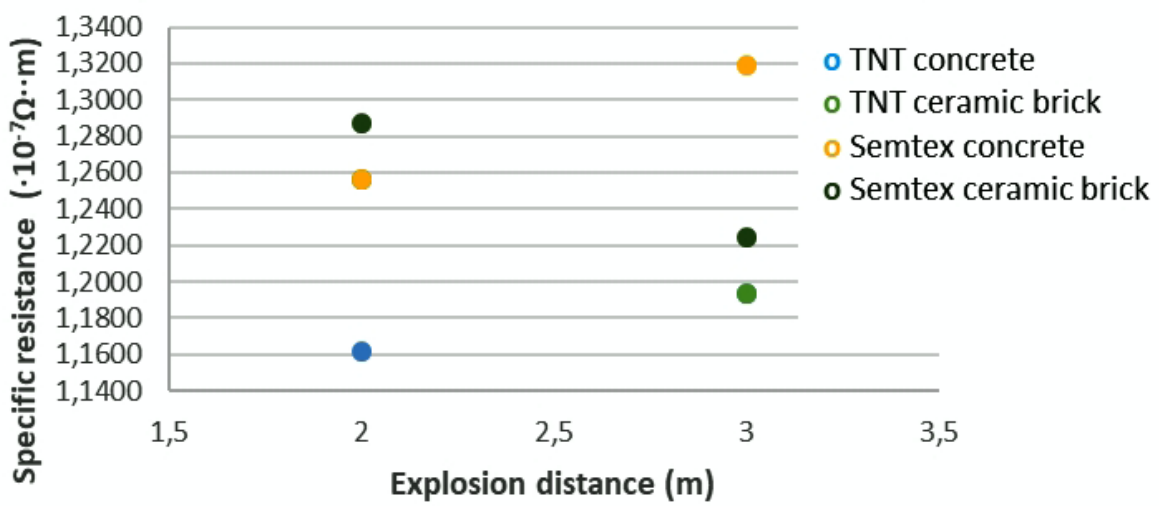

Figure 6. The specific resistance as a function of the explosion distance and the explosive material 
plan to investigate the microstructure and the dislocation number changes after the blast load.

\section{References}

[1] Figuli L., Jangl Š., Papán D.: Modelling and Testing of Blast Effect on the Structures. In: IOP Conference Series: Earth and Environmental Science 44/5. (2016).

[2] Figuli L., Štaffenová D.: Practical Aspect of Methods Used for Blast Protection. In: Key Engineering Materials 755. (2017) 139-146. Trans Tech Publications, Switzerland.

[3] Figuli L., Bedon C., Zvaková Z., Jangl Š., Kavický V.: Dynamic analysis of a blast loaded steel structure. Procedia Engineering, 199. (2017) 2463-2469.

[4] Figuli L., Jangl Š., Papán D.: Modelling and Testing of Blast Effect On the Structures. IOP Conference Series: Earth and Environmental Science, 44/5. (2016).

[5] Lukács L., Szalay A., Zádor I.: Explosive forming and the aerospace. Repüléstudományi Közlemények, vol. XXIV/2. (2012) 431-446.
[6] Daruka N.: IEDD - Improvised Explosive Device Disposal. In: International Conference on Military Technologies - ICMT 2013, 383-390 (2013).

[7] Ashby M. F., Jones D. R. H: Engineering Materials. An Introduction to Properties, Applications and Design. Third Edition, Elsevier 2005. Cambridge, UK P.K.

[8] Kovács T.: Explosive Surface Hardening of Austenitic Stainless Steel. In: Iop conference series: Materials Science and Engineering 123. (2016) 1-5.

[9] Ramos M. J. G., et all: Dependence of Electrical Risistivity on Plastic Deformation on Copper-Aluminium Alloy Cu0,975Al0,025. Journal of Metals, Materials and Minerals, 26/2. (2016) 31-36. https://doi.org/10.14456/jmmm.2016.9

[10] Meyers M. A. Mura E., Staudhammer K. P.: Shockwave and high-strain-rate phenomena in metals. Marcel Dekker Inc., New York, 1992.

[11] Draganic H., Sigmund V.: Blast load on structures. In: Technical Gazette, 19/3. (2012) 643-652 